\title{
TEPUNG PUPA-MULBERRY (PURY) SEBAGAI BAHAN PANGAN ALTERNATIF KAYA GIZI
}

\author{
(Pupa-Mulberry (PURY) Powder as an Alternative Nutritious Food Source) \\ Trina Astuti ${ }^{1}$ dan Clara M. Kusharto ${ }^{2 *}$ \\ 1 Program Studi Gizi Manusia, Sekolah Pascasarjana, Institut Pertanian Bogor \\ 2* Departemen Gizi Masyarakat, Fakultas Ekologi Manusia, Institut Pertanian Bogor, Bogor 16680. \\ Tel: 0251-8621258; Fax: 0251-8622276; Email: kcl@indo.net.id
}

\begin{abstract}
Silkworm pupae is immature stage of moth. It is inner part of the silkworm cocoon shell which usually disposed from yarn silk production, and now has become a valuable ingredient of human food in many countries, however it is not common yet in Indonesia. The purpose of study is to develop a weaning food as nutritious basic formula of complementary food from pupae waste. A silkworm pupae was a major constituents used as materials. There are sixth steps to get PURY properly: select a fresh, fine and clean pupae, steamed well about 10 seconds, grinded and sifted it to get liquid, added $10 \%$ maize powder, dried in oven at $60^{\circ} \mathrm{C}$ for 6 hours, and refine on blender. A fine powder, so called "PURY", has a well balanced amount of moisture, protein, fat included PUFA, carbohydrate, amino acids, vitamins and minerals. Through a simple processing, the dry product of fine PURY powder can be obtained and used as a basic formula of complementary food and snacks and has made great contribution to reduce pupae waste. Research is continued to scale up producing PURY based product for more foodtechnological uses in order to reduce prevalence of malnutrition in Indonesia.
\end{abstract}

Keywords: silkworm, pupae waste, PURY, complementary food, malnutrition

\section{PENDAHULUAN}

Kegiatan persuteraan alam di Indonesia sudah ada sejak abad ke 10 dan mulai masuk Sulawesi Utara tahun 1932, kemudian mulai intensif di Sulawesi Selatan pada tahun 1960. Sekarang budi daya sutera sudah dikembangkan di luar Sulawesi, yaitu di J awa Barat, Tengah, dan Timur, Sumatera barat, Jogya, dan Bali (Kaomani, 2006).

Produk benang sutera pada tahun 2005 sebesar 69.45 ton (Badan Planologi Kehutanan, 2007) dan Pemerintah mentargetkan mencapai 400 ton per tahun, yang berarti memerlukan kokon sebanyak \pm 2667 ton per tahun. Kendala yang muncul adalah bagaimana memanfaatkan limbah pupa yang mencapai \pm 2267 ton per tahun agar tidak menimbulkan polusi.

Pupa adalah bagian isi dari kokon yang merupakan produk sampingan dari industri pembudidayaan ulat sutera, yang bila tidak ditangani dengan baik akan mencemari lingkungan karena bau busuk yang menyengat, mengundang lalat dan belatung, serta dapat mencemari sumber air minum. Di negara Cina, pupa telah dimanfaatkan sebagai pangan (asam amino pupa untuk soft drink dan bahan aditif cookies dlI), juga di Korea (snack dan diet DM) dan Bangladesh (Singhal et al., 2001). Di Indonesia, pupa masih belum berkembang pemanfaatannya sebagai sumber pangan, padahal mengandung unsur gizi seperti protein, asam lemak tak jenuh, juga vitamin dan mineral serta asam amino esensial maupun nonesensial yang sangat dibutuhkan bagi tumbuh kembang anak.

Pupa yang berasal dari ulat sutra Mulbery yang dibuat tepung (powder) selanjutnya disebut PURY berpotensi sebagai sumber pangan yang bergizi. Diharapkan dengan tersedia tepung PURY dari limbah pupa dapat meningkatkan ketersediaan bahan pangan sumber protein hewani yang padat gizi.

Tujuan dari studi adalah untuk mengembangkan sumber bahan pangan dari limbah pupa yang padat gizi bagi konsumsi penduduk sekitar sentra industri benang sutera. Manfaat yang diharapkan adalah dapat mengurangi cemaran lingkungan sekaligus mendukung program Pemerintah menurunkan prevalensi gizi kurang pada bayi usia 6-12 bulan melalui formula PURY-MPASI, khususnya bagi masyarakat sekitar sentra industri sutera. 


\section{METODE}

\section{Waktu dan Tempat Penelitian}

Penelitian ini dilakukan di Laboratoriun Fisik Terpadu Fakultas Ekologi Manusia Institut Pertanian Bogor. Penelitian dilaksanakan pada bulan Juli hingga Desember 2007. Analisis tepung PURY dilakukan di 2 laboratorium, yaitu laboratorium terpadu IPB dan Laboratorium Pusat Penelitian dan Pengembangan Gizi Bogor.

\section{Bahan dan Cara}

Bahan yang digunakan adalah limbah pupa yang merupakan produk samping benang sutera yang diperoleh dari sentra-sentra pemintalan benang sutera di J awa barat dan Sulawesi Selatan.

Metode yang digunakan untuk mengetahui keamanan dan komposisi zat gizi PURY antara lain: calorimeter bom, gravimetri, titrimetri, mikrobiologi, dan spektofotometer serapan atom.

Untuk mendapatkan hasil tepung (PURY), limbah pupa harus diolah segera setelah pemintalan benang sutera selesai. Langkah pertama yang harus dilakukan, yaitu memisahkan limbah pupa yang masih baik dan membuang pupa yang kurang baik (kecil, busuk, keriput, dan lainnya). Setelah itu di cuci minimal 3 kali untuk membuang lendir dan kotoran lain yang menempel, kemudian ditiriskan. Lalu siapkan dandang yang di isi sedikit air di atas api. Setelah air mendidih masukkan pupa dan tutup rapat. Setelah \pm 10 menit angkat dandang dan buka tutupnya. Untuk mendapatkan liquid pupa, masukkan pupa yang sudah dikukus ke dalam saringan kawat yang bersih dan kuat kemudian diuleg atau digerus. Tetesan liquid ditampung di baskom, sedangkan kulit pupa dapat digunakan sebagai pakan ikan (dalam keadaan segar atau dikeringkan). Langkah selanjutnya adalah mengisi liquid dengan bahan lain, yaitu tepung maizena sebanyak $10 \%$ Campuran diaduk dan dikeringkan dengan oven selama 6 jam pada suhu $60^{\circ} \mathrm{C}$, kemudian angkat dan blender agar halus (Gambar 1).

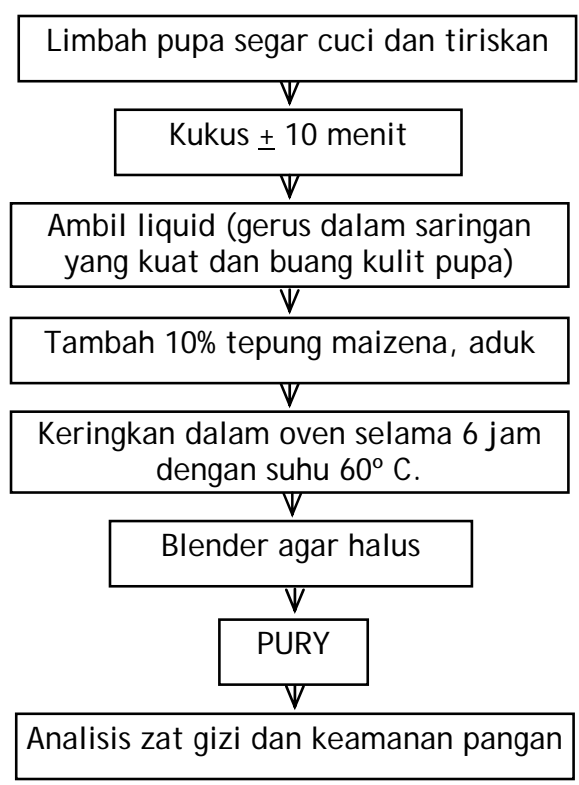

Gambar 1. Skema Pembuatan PURY

\section{HASIL DAN PEMBAHASAN}

Hasil yang sempurna akan ditunjukkan secara fisik dengan warna tepung yang cerah kuning kecoklatan dan aroma yang gurih sedap. Hasil analisis tes cemaran mikro organisme pada Tabel 1, sedangkan komposisi zat gizi, asam lemak dan asam amino dapat dilihat pada Tabel 2, 3, dan 4 berikut.

Proses pengeringan yang menyangkut suhu dan durasi pengeringan sangat mempengaruhi hasil. Bila suhu terlalu tinggi maka hasil PURY akan berwarna coklat tua, demikian pula bila waktu pengeringan kurang, maka PURY akan berwarna kehijauan dengan aroma yang tidak sedap. Pada suhu dan waktu yang tepat akan menghasilkan warna yang cerah kuning kecoklatan (krem), tekstur kering dan renyah (tidak menggumpal), dan aroma sedap yang mengundang selera.

Proses pengeringan dapat dilakukan dengan teknologi tinggi, yaitu dengan Drum Dryer yang dapat menghasilkan tepung $10 \mathrm{~kg}$ per hari, dengan kekeringan yang konstan namun perlu tempat, alat dan tenaga khusus

Tabel 1. Test Cemaran Mikro Organisme dalam Tepung PURY.

\begin{tabular}{lccc}
\hline \multicolumn{1}{c}{ Parameter } & Satuan & Kadar & Teknik Analisis \\
\hline Total Plate Count & Colony/g & $5.8 \times 10^{3}$ & Microbiology \\
Colifirm & Colony/g & $7.5 \times 10^{1}$ & Microbiology \\
E. Coli & Colony/g & $1.5 \times 10^{1}$ & Microbiology \\
Staphylococcus aureus & Colony/g & Negatif & Microbiology \\
Salmonella / shigella & Colony/ $25 \mathrm{~g}$ & $2.0 \times 10^{1}$ & Microbiology \\
\hline
\end{tabular}


Tabel 2. Komposisi Zat Gizi dalam 100 gram Tepung PURY.

\begin{tabular}{|c|c|c|c|}
\hline Parameter & Satuan & Kadar & Teknik analisis \\
\hline Energi & $\mathrm{Cal} / \mathrm{g}$ & 4826 & BombCalorimetry \\
\hline Kadar air & $\% w / w$ & 10.40 & Gravimetry \\
\hline Abu & $\% w / w$ & 3.14 & Gravimetry \\
\hline Protein & $\% w / w$ & 33.44 & Titrimetry (Kj eldahl) \\
\hline Lemak & $\% w / w$ & 25.72 & Gravimetry (Soxhlet) \\
\hline Karbohidrat & $\% w / w$ & 5.54 & Spectrometry \\
\hline Dietary Fiber & $\% w / w$ & 0.22 & Gravimetry \\
\hline Fiber & $\% w / w$ & 0.71 & Gravimetry \\
\hline \multicolumn{4}{|l|}{ Mineral : } \\
\hline $\mathrm{Fe}$ & ppm & 30.79 & AAS \\
\hline Kalsium (Ca) & $\mathrm{ppm}$ & 1162.53 & AAS \\
\hline Zinc (Zn) & ppm & 95.68 & AAS \\
\hline Selenium (Se) & $\mathrm{ppm}$ & $\varangle 0.002$ & AAS \\
\hline Sodium, Na & ppm & 300.48 & Spectrophotometry \\
\hline Phosphor, P & $\mathrm{ppm}$ & 5874.56 & AAS \\
\hline lodine* & $\mathrm{ppm}$ & 45 & Spectrometry \\
\hline \multicolumn{4}{|l|}{ Vitamin :* } \\
\hline A & Mcg/ $100 \mathrm{~g}$ & 277 & Spectrophotometry \\
\hline B1 (Thiamin) & $\mathrm{Mg} / 100 \mathrm{~g}$ & 0.66 & Spectrophotometry \\
\hline B12 (Riboflavin) & $\mathrm{Mcg} / 100 \mathrm{~g}$ & 0.24 & Microbiology \\
\hline Asam Folat & Mcg/ $100 \mathrm{~g}$ & 68.21 & Microbiology \\
\hline
\end{tabular}

Tabel 3. Komposisi Asam Lemak dalam 100 gram Tepung PURY.

\begin{tabular}{llrc}
\hline \multicolumn{1}{c}{ Parameter } & Satuan & Kadar & Teknik analisis \\
\hline AsamLemak (unit \% w/w in fat/oil): & \%w/w & & $\mathrm{GC}$ \\
C14:0 (Miristic) & & 0.16 & \\
C16:0 (Palmitic) & & 21.81 & \\
C18:0 (Stearaic) & & 4.85 & \\
C18:1 (Oleic) & & 32.71 & \\
C18:2 (Linoleic) & & 4.35 & \\
C18:3 (Linolenic) & 19.20 & \\
C20:0 (Arachidic) & 0.21 & \\
C22:0 (Behenic) & & 0.04 & \\
C22:1 (Erucic) & 0.04 & \\
\hline
\end{tabular}

Tabel 4. Komposisi Asam Amino dalam 100 gram Tepung PURY.

\begin{tabular}{lccc}
\hline \multicolumn{1}{c}{ Parameter } & Satuan & Kadar & Teknik analisis \\
\hline Asam Amino & $\% \mathrm{w} / \mathrm{w}$ & & \\
Aspartic acid & & 2.46 & \\
Glutamic acid & & 2.85 & \\
Serine & & 0.84 & \\
Histidine & 0.81 & \\
Glycine & 1.83 & \\
Threonine & 0.92 & \\
Arginine & 1.18 & \\
Alanine & 1.16 & \\
Tyrosine & 1.40 & \\
Methionine & 1.04 & \\
Valine & 1.38 & \\
Phenylalanine & 1.24 & \\
I-leucine & 1.15 & \\
Leucine & 1.74 & \\
Lycine & & 2.00 & \\
\hline
\end{tabular}

serta daya listrik yang besar. Penggunaan oven rumah tangga dapat dilakukan kapan saja dan dimana saja disekitar sentra pemintalan sutera. Bahan bakar dapat menggunakan gas ukuran $12 \mathrm{~kg}$ untuk 10 kali pengeringan, namun kapasitas per hari untuk satu oven rumah tangga hanya mencapai $2 \mathrm{~kg}$ produksi tepung. Kesempurnaan hasil dapat bervariasi tergantung pengontrolan yang dilakukan.

\section{Keamanan Pangan}

Hasil tes cemaran mikro organisme menunjukkan bahwa Total Plate Count) (TPC) dalam PURY (5800/gr) masih dibawah ketentuan Departemen Kesehatan RI (10 000/gr), demikian pula dengan kandungan 
Staphylococcus aureus yang negatif per gram bahan (Depkes, 2006). Beberapa mikro organismne seperti Eshecia Coli dan Salmonella atau Shigella sedikit diatas ambang batas yang dianjurkan, namun tidak berbahaya karena akan hilang dalam proses pemasakan. PURY dipastikan aman sebagai bahan pangan karena PURY tidak dikonsumsi langsung tetapi masih diolah lebih Ianjut. Misal digunakan untuk formula MP-ASI bayi 6-12 bulan dalam bentuk bubur atau biskuit, maka perlu dimasak terlebih dahulu walau hanya 5 menit. Dengan demikian mikro organisme patogen akan mati. PURY juga dapat digunakan sebagai bahan pembuatan kerupuk dan kue bagi konsumsi anak-anak dan orang dewasa.

\section{Komposisi Zat Gizi}

Kadar air sangat penting untuk menentukan parameter mutu, yaitu sangat menentukan kualitas mutu produk dari segi fisik, kimia, dan mikrobiologi. Tabel 2 menunjukkan bahwa kadar air pada tepung PURY sekitar $10.4 \%$ yang berada dibawah kadar air tepung terigu, yaitu 12\% (Winarno, 1992). Berdasarkan hal tersebut maka produksi PURY dapat dikatakan memenuhi syarat fisik untuk kadar air, sehingga kerusakan fisik, kimia, dan mikrobiologi dapat dicegah lebih lama yang berarti meningkatkan daya simpan hasil produksi tersebut.

Kandungan protein dalam PURY juga tinggi (33.44\%) yang berarti mempunyai nilai biologi tinggi karena dengan kadar protein tinggi dapat mencerminkan susunan asam aminonya yang relatif lengkap (Tabel 4). Penggunaan tepung PURY sebagai sumber protein sangat bermanfaat bagi pertumbuhan bayi dan anak di lingkungan sentra produksi sutera.

Kandungan Zat gizi mikro seperti vitamin dan mineral sangat rinci merupakan keunggulan PURY sebagai alternatif bahan formula MP-ASI. Keunggulan Iain dari PURY adalah kandungan asam lemak tak jenuh seperti oleic, linoleic, dan linolenic (56,3\%) yang dua kali lebih banyak dari kandungan asam lemak jenuh (miristat, palmitat, stearat, dan arachidonat) dalam PURY (sekitar $27 \% \mathrm{w} / \mathrm{w}$ ) yang merupakan bahan dasar pembentukan otak bayi dan anak. Bila dicampur dalam formula MP-ASI bagi bayi usia 6-12 bulan, PURY dapat digunakan sebagai sumber protein, lemak khususnya lemak tak jenuh, vitamin, dan mineral yang akan memberikan dampak yang positif bagi tumbuh kembang anak.

\section{Analisis Biaya}

Modal dasar yang merupakan biaya tetap tentu lebih besar bila menggunakan drum dryer dibanding oven rumah tangga ( $R p$ 100 juta Vs Rp 1.1 juta). Biaya pembuatan tepung juga berbeda jauh antara kedua cara proses pengeringan. Bila asumsi sama dalam mendapatkan bahan mentah (limbah pupa) maka harga per $\mathrm{kg}$ tepung yang dibuat dengan oven ( $R p 20$ 000/ kg) lebih murah dibanding harga pembuatan dengan drum dryer (Rp 60.000/ kg).

\section{KESIMPULAN}

Pengolahan limbah sutera sangat menguntungkan untuk meningkatkan ketersediaan bahan pangan yang padat gizi, sekaligus menurunkan cemaran lingkungan. Perlu adanya sosialisasi dan peran Pemerintah Daerah untuk memberdayakan masyarakat sekitar sentra pemintalan benang sutera untuk memanfaatkan PURY sebagai bahan pangan alternatif, menambah pendapatan peternak ulat sutera, dan menjaga lingkungan sekitar dari pupa yang biasanya terbuang begitu saja.

\section{DAFTAR PUSTAKA}

Departemen Kesehatan RI. 2006. Pedoman Umum Pemberian Makanan Pendamping ASI Lokal. Depkes RI, J akarta.

Kaomani K. 2006. Pengenalan Kegiatan Persuteraan Alam. Puslitbang Hutan dan Konservasi Alam. Bogor.

Singhal BK, Dhar A, Sharma A, Qadri SMH \& Ahsan MM. 2001. Serisultural byProduct for Various Valuable Commercial Product as Emerging Bio Science Industry. Sericologia 41(3), 369-391.

WHO. 1998. Complementary Feeding of Young Children in Developing Countries: a review of current scientific knowledge. WHO, Geneva.

Winarno FG. 1992. Kimia Pangan dan Gizi ed.6. Gramedia Pustaka Utama, J akarta. 